\title{
A MEW és az ISEW alternatív gazdasági mutatók elméleti áttekintése
}

\author{
Varga József,, Bánkuti Gyöngyi, ${ }^{1}$ Csuvár Ádám, ${ }^{3}$ Sebestyénné Szép Tekla ${ }^{4}$
}

\begin{abstract}
A Theoretical Overview of Alternative Economic Indicators MEW and ISEW. In our publication we focus on the economic well-being indicators that can be good substitutes or alternatives of the gross domestic product. After the brief overview of the often mentioned weaknesses and mistakes of GDP, we present the Measure of Economic Welfare (MEW) and the Index of Sustainable Economic Welfare (ISEW). We summarize that albeit there are more than enough indicators, none of them is so widely accepted as GDP. It is not clear yet which one(s) will replace it in its role. The study was created for the Economics Seminar of Kaposvár(KAKTUSZ) which is organized annually by the Kapos vár University. Another research teamof the environmental economics session of KAKTUSZ 2016 undertakes to demons trate other alternative economic indicators in the article titled "Theoretical overview of the GPI, the SNBI and the HDI alternative economic indicators" by Csuvár et al. (2018).
\end{abstract}

Keywords alternative economic indexes, well-being, wealth indexes, MEW, Measure of Economic Welfare, ISEW, Index of Sustainable Economic Welfare

\section{Bevezetés}

A nagy gazdasági világválság idején az Egyesült Államok Kereskedelmi Minisztériuma a fiatal oroszközgazdás zt, Simon Kuznetset bízta meg azzal a feladattal, hogy alkosson meg egy olyan els zámolási rendszert, amely alkalmas a gazdaság növekedésének, reces szióból való kilábalásának tendenciájának mérésére. A mutató 1934-re elkés zült és majd' 10 évre rá, a Bretton Woods-i konferenciát követően tovább fejlődött és nemzetközileg is elfogadottá vált. Ez az index a bruttó hozzáadott érték, vagyis a GDP.

${ }^{1}$ Kaposvári Egy etem, Gazdaságtudományi Kar

Email: varga.jozsef@ke.hu

${ }^{2}$ Kaposvári Egy etem Gazdaságtudományi Kar

Email: bankuti.gy ongyi@ke.hu

${ }^{3}$ Kaposvári Egy etem, Gazdaságtudományi Kar

Email: csuvar.adam@ke.hu

${ }^{4}$ Miskolci Egyetem, Gazdaságtudományi Kar

Email: szep.tekla@uni-miskolc.hu 
Számtalanszor találkozhatunk vele gazdasági, politikai okfejtésekben a siker egyik legfontosabb mércéjeként, ám ha közelebbről is megvizsgáljuk, használata számtalan ellentmondást indukál. A mutató rövidke története is érzékelteti a manapság egyre gyakrabban hangoztatott gyengeségét, mis zerint alkalmatlan területi összehas onlításokra, hiszen eredendően sem ezért jött létre. Emellett maga Kuznets is felhívta a figyelmet arra, hogy a mutató a vizs gált térség életszínvonalának meghatározására nem alkalmas, egy fơre számított értékét azonban mégis gyakorta alkalmazzák e cél érdekében. A GDP-t érintő éles kritikák sorát vonultathatnánk még fel, s zámos jobbnak tűnő alternatíva született már leváltására, mégis úgy fest, a trónfosztás jócskán várat magára. Cikkünk során a GDP-vel kapcsolatos dilemmák rövid körül járása után két alternatív gazdasági mutatót ismertetünk.

\section{A GDP mutatószámrendszer előnyei és alkalmatlansága}

Közgazdasági elemzés ekben általánosan elfogadott a GDP, mint a gazdasági növekedés mérőszáma. A GDP elterjedtsége nem szofisztikáltságának köszönhető, hanem annak, hogy adott feladatra könnyen értelmezhető és összehasonlítható eredményt, számot ad. Ezzel együtt a GDP növekedése sok esetben félrevezető, hiszen tartalmazza például a fegyverkezés, a honvédelem, az egészségügyi ellátás vagy a büntetés-végrehajtás költségeit, a természeti katasztrófák helyreállítására fordított kiadásokat, amelyek így haszonként értékelődnek a mutató kiszámításakor. Ezzel szemben a természetierőforráskészletek változásáról semmit sem mond. Érdekes szempontot vet fel Bánfi, szerinte a nagy országok GDP-jének jelentős része a társadalom és a természet számára kártékony tevékenységekből adódik. Úgy véli, a GDP-arányos mutatószám rendszer (pl. államháztartási deficit, államadósság) esetében a használat előtt a GDP-t indokolt volna megtisztítani a romboló termelés és szolgáltatások negatív hozadékától. ${ }^{5}$

A GDP mégis talán legnagyobb hiányossága, hogy a nem monetarizált kapcsolatokat, vagyis a háztartások és a társadalom nem piaci tevékenységének értékét nem tartalmazza, ${ }^{6}$ Egészen más adatok mutatkoznak például akkor, ha a lakásépítés jelentős része lakossági munkavégzés (kaláka) keretében megy végbe, vagy ha építőiparra szakosodott cégek, profitorientáltan végzik e tevékenységet. Ahogy Bánfi rámutat: „A GDP-nek nem az az alapvetö hibája, hogy mit nem tartalmaz (pl. a lakosság jó hangulatát, a nök szépségét, a férfiak fizikai erejét, vagy akár a nök és a férfiak kielégitettségét), mert nem ,boldogság-indexnek" szánjuk, hanem az, amit tartalmaz."7 Ezt a problémát csak részben orvosolja a vásárlóerő-paritáson mért GDP számítás.

Nemzetközi összehasonlítás ban olyan országok esetében, amelyek jelentős regionális különbségekkel rendelkeznek, az eltérő monetarizáltsági szint miatt más-más eredmények születnek a GDP használatakor. A mutató szintén gyakran emlegetett hátránya, hogy nem veszi figyelembe a jövedelmi egyenlőtlenségeket, tehát az értéke növekedhet, annak ellenére, hogy a szegények szegényebbekké, a gazdagok gazdagabbakká válnak. ${ }^{8}$ Kerekes arra hívja fel a figyelmet, hogy a részvénytársasági kapitalizmus elterjedése révén ,a GDP-t még földrajzilag sem ott használják fel, ahol megtermelték, tehát csak

\footnotetext{
${ }^{5}$ Bánfi, 2012.

${ }^{6}$ Kerekes, 2007.

${ }^{7}$ Bánfi, 2012.

${ }^{8}$ Daly, 1990; Ayres, 1998.
} 
részben gazdagítja azt a társadalmat, aminek a problémáinak a megoldására volna hivatott. ",

A közgazdászok körében egyre inkább egyetértés uralkodik abban a kérdésben, hogy a GDP nem alkalmas a gazdasági jólét, a gazdasági fejlődés mérésére. Amint már említettük, a GDP mutatója nem a jólét, hanem adott régióban, adott időszak alatt végbemenő gazdasági tevékenységek, a gazdasági növekedés mérésére lett kifejlesztve. A növekedés üteme viszont önmagában nem árul el semmit annak externális hatásairól, szerkezetéröl. Ennek ellenére mind a mai napig a legtöbb nemzetállam gazdaságpolitikájának középpontjában a gazdasági növekedés, azaz pusztán a GDP értékének növelése áll. Ezt sok esetben a gazdasági fejlődéssel, az állampolgárok jólétének növekedésével azonosítják, melyet a bruttó hozzáadott értékkel számszerüsítenek. Ugyanakkor az európai ors zágokban mért GDP-t és a migrációs rátát összehasonlítva látható, hogy a gazdagabb országokat többen válas ztották ideiglenes vagy végső lakh elyül, míg a szegényebb országokat tömegesen elhagyták. Általános érvényűnek tekinthető, hogy a kibocsátó országok jelentősebb munkanélküliséggel küzdenek, de többnyire nem a magas munkanélküliséget tekinthetjük a nagyobb kivándorlás egyedüli kiváltó tényezőjének, bár ez a hatás nem elhanyagolható. ${ }^{10}$

Érdemesnek tartjuk megemlíteni az $\mathrm{AIC}^{11}$ indexet, amelyet korrigált mutatószámként használnak a GDP helyett. A mutató a háztartások fogyasztását méri, továbbá tartalmazza az állami vagy akár nonprofit szolgáltatásokat is. Jellege nagyon jól egyezik a GDP görbéjével, mivel ez utóbbi is nagy hangsúlyt fektet az említett tényezőkre. Erre mutat rá a válság utáni európai uniós helyzet elemzésében Gerstberger és Yaneva ${ }^{12}$ ( 1 . ábra).

\section{1. ábra. A GDP, az AIC valamint a háztartás ok és az állami szektor fogyasztásai- nak változás ai a válságot megelőző és követő időkben az Európai Unióban (\%)}

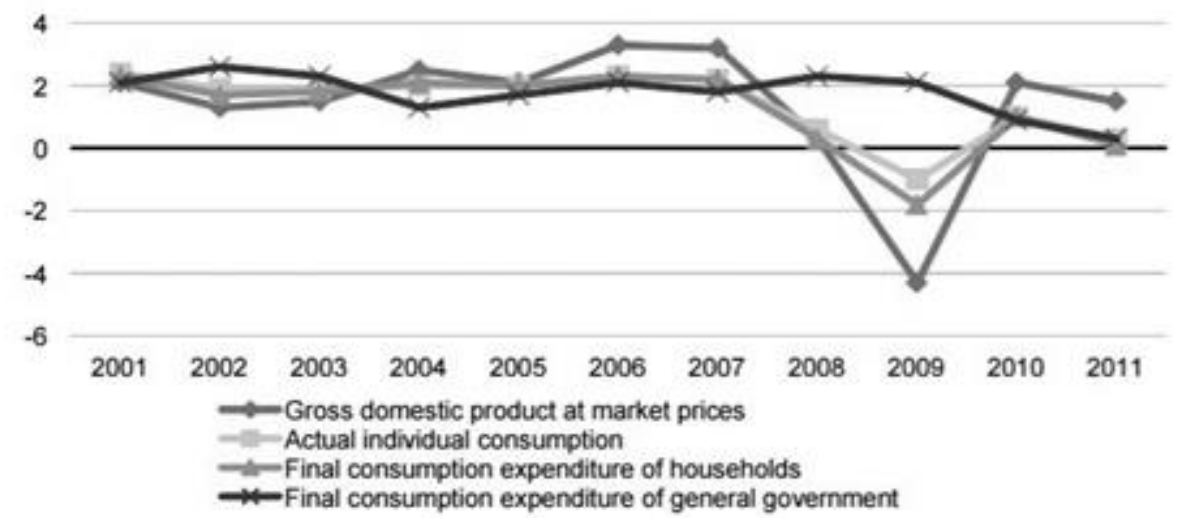

Forrás: Gerstberger és Yaneva, 2013. Adatbázis: http://appsso.eurostat.ec.europa.eu /nui/show.do?dataset=nama_fcs_k\&lang=en

\footnotetext{
${ }^{9}$ Kerekes, 2015, 13.

${ }^{10}$ Péter, 2013.

${ }^{11}$ Actual Individual Consumtion, tényleges egyéni fogyasztás.

${ }^{12}$ Gerstberger \& Yaneva, 2013.
} 


\section{Alternatív gazdasági mutatószámok áttekintése}

\section{$M E W^{13}$}

A GDP fenti hiányosságai következtében egyre inkább előtérbe kerülnek az alternatív mutatószámok. Ebben a fejezetben kettő ilyen rendszer rövid áttekintésére vállalkozunk. Az alternatív mutatószámok kidolgozásának gyökere a skandináv modell. Ez az elképzelés az életminőség objektív elemeit állítja előtérbe (Drewnoski, Titmuss munkássága $\left.{ }^{14}\right)$, amely szerint az egyének erőforrások feletti rendelkezését döntően az egyének külső körülményei határozzák meg. A további kezdeményezésekben lényeges William Nordhaus szerepe. 1972-ben ő és James Tobin dolgozta ki elsőként a gazdasági jólét mérésére alkalmas mutatót, a MEW-t. ${ }^{15} \mathrm{~A}$ gazdasági jólét mércéje a bruttó hazai termék mellett tartalmazza a szabad idő és a piac által nem közvetített egyéb gazdasági tevékenységek (pl. házimunka) pénzbeli értékét. Bizonyos végső kormányzati kiadásokat közbenső kiadásokká, fogyas ztássá vagy beruházás sá konvertál át. Így az oktatás és az egészségügy ráfordításait például termelékenységet növelö beruházásként könyveli el, míg bizonyos kiadások (pl. rendőrség) a köztes, semleges kategóriába kerülnek. A MEW értelmezése szerint a tartós fogyasztási cikkek tőkejavak, amik némi értéknövelő hatással bírnak. Negatív tényezőként veszi számításba az urbanizáció, az ipari termelés környezetromboló hatásait. Tanulmányában Nordhaus arra a következtetésre jutott, hogy az Amerikai Egyesült Államokban 1929 és 1965 között a MEW és a GNP nagyon jól korrelál egymással, így általánosan elfogadottá vált, hogy ez utóbbi mutató is alkalmas a jólét mérésére, ezért nem indokolt a MEW használata. Megalkotása azonban jó ösztönzésnek bizonyult további alternatív indexek kifejlesztéséhez.

\section{ISE $W^{16}$}

A későbbiekben Daly és Cobb korrigálta a MEW-t és megalkotta az ISEW mutatót. ${ }^{17}$ Az ISEW két lényeges ponton lép tovább a MEW-n. Egyrészt figyelembe veszi a fogyasztási egyenlőtlenségek változásának jólétre gyakorolt hatásait, másrészt a mutató tartalmazza a hosszú távú környezeti károk jelenértékét is. Az ISEW a lakossági fogyasztásból indul ki, és ehhez adja hozzá, vagy ezekből vonja le az egyes tényezőket. A lakossági fogyasztás ba beletartozik mind a saját jövedelmek, mind a társadalmi juttatások (pénzbeli és természetbeni egyaránt) által finanszírozott, valamint a saját termelésü javak fogyasztása. ${ }^{18}$ A MEW és az ISEW GDP-hezképesti csökkenése főképpen a hoszszú távú környezeti károk súlyának növekedésével, a fokozódó jövedelemeloszlási egyenlőtlenségek számbavételével magyarázható.

\footnotetext{
${ }^{13}$ Measure of Economic Welfare, gazdasági jólét mércéje.

${ }^{14}$ Kerekes, 2007.

${ }^{15}$ Nordhaus \& Tobin, 1972.

${ }^{16}$ Index of Sustainable Economic Welfare, fenntartható gazdasági jólét indexe.

${ }^{17}$ Clarke \& Lawn, 2008.

${ }^{18}$ Tanulmányunk kereteit szétfeszítené az ISEW módosításával létrehozott ISEW* mutató elemzése. Erre azért volt szükség, mert az ISEW mutató egyes tényezőinek meghatározása nagy részt becsléseken alapul, a kimerülő erőforrásokból származó költségekre és a hosszú távú körny ezeti károkra vonatkozó becsléseiket különösen bizonytalanok, ezért e két tétel mellőzésével került kiszámításra a módosított ISEW-mutató.
} 
Az ISEW „,...rendkivül összetett méröszám, ami sajnos hátrányként jelentkezik, ha az adatok összegyüjthetőségét nézzük. Sok országban, igy Magyarországon is, semállnak rendelkezésre a szükséges statisztikai adatok."19

A mutató elméleti elemzését magyarul Málovics és szerzőtársai teszik meg. Kiszámításának algoritmusa: „ISEW $=\mathrm{C}_{\mathrm{kiig}}+\mathrm{P}+\mathrm{G}+\mathrm{W}_{\mathrm{i}}-\mathrm{D}_{\mathrm{i}}-\mathrm{E}_{\mathrm{i}}-\mathrm{N}_{\mathrm{i}}$ ahol $\mathrm{C}_{\mathrm{kiig}}$ a jövedelem egyenlőtlenségekkel kiigazított fogyasztói kiadások, $\mathrm{P}$ a nem-defenzív közkiadások, $\mathrm{G}$ a tőkenövekmény és a nemzetközi pozíció nettó változása, W a jólétet növelő nem monetáris tételek, D a privát védekezési kiadások, E a környezet leromlásának költségei, és $\mathrm{N}$ a természeti tőke értékcsökkenése. A mutató logikája a GNP-éhez hasonló, azaz a mutató a maximum lehetséges fenntartható fogyasztás indikátora akar lenni (Hanley et al., 1999)."20 Megjegyzik, hogy egy fenntarthatósági mutatónál fontos szempont lehet annak politikai relevanciája, vagyis, hogy annak összetétele mennyire lehet jó alap szakpolitikák megalkotásához, elemzéséhez. ${ }^{21}$

AZ ISEW mérését már több ors zágban bevezették, például Ausztriában, Hollandiában, Németországban, Olaszországban, Svédországban, Chilében. Adatok az 50-es évek óta érhetőek el rá, alakulásuk az alábbi grafikonokon látható (2-6. ábra).

\section{2-6. ábra. Ausztria, Chile, Németország, Olaszország, Hollandia, Svédország GDP és ISEW mutatóinak összehasonlító grafikonjai}
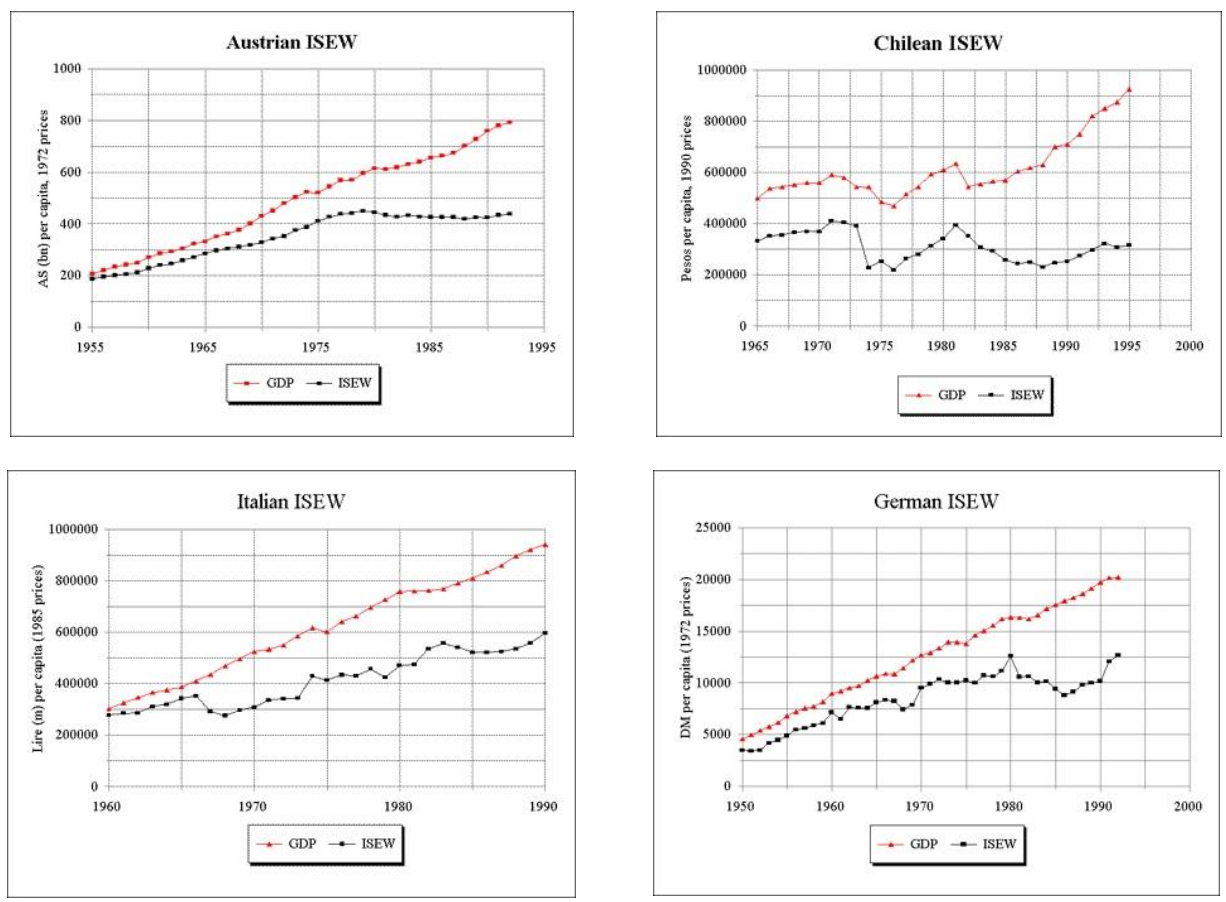

\footnotetext{
${ }^{19}$ Unyi, 2007, 33.

${ }^{20}$ Málovics, 2012., 277.

${ }^{21}$ Málovics, 2012.
} 

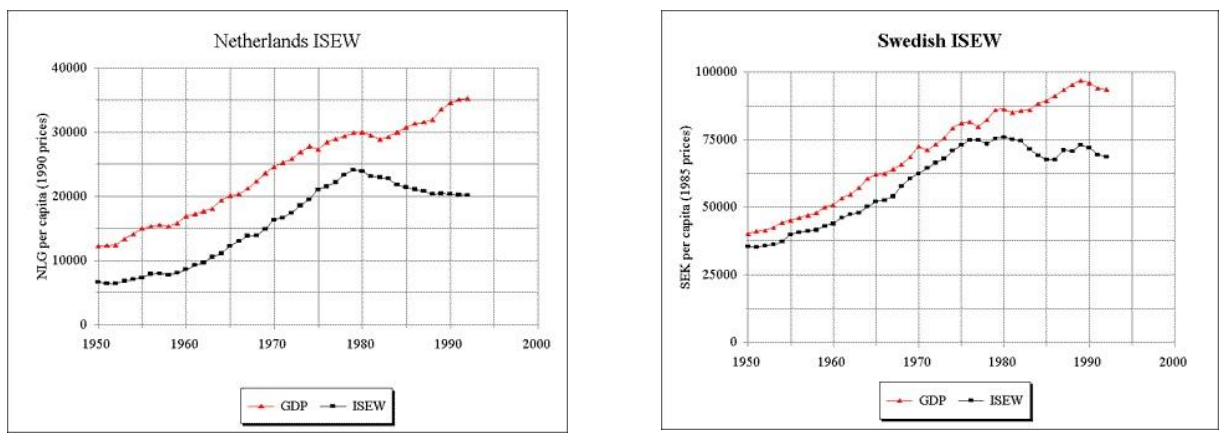

Forrás: Anielski Management, http://www.anielski.com/alberta-international-gpiisew-graphs/

A 2-6. ábrákon alapján látható, hogy azISEW lassabb ütemben bár, de körülbelül 1980-ig együtt mozgott, nőtt a GDP-vel, utána azonban legtöbb ország esetén a két mutató eltávolodott egymástól. A GDP és az ISEW korrelációjára vonatkozó vizsgálatok szerint az indexek alakulása az első olajárrobbanást követően vált el egymás tól (az Amerikai Egyesült Államokban). ${ }^{22}$ A továbbiakban általában a GDP növekedése az ISEW kezdeti csökkenése mellett ment végbe. Ausztriában az ISEW mutató stagnált, Olaszországban pedig némi stagnálással, de tovább növekedett. Ez a visszanövekvő tendencia más országokban is jelentkezik a későbbiekben az ábrákon látható módon. Az USA-ra sajnos nem találtunk GDP-vel összehasonlító grafikont csak az alábbi országokkal történő összehasonlítást. Láthatóan azEgyesült Államokban esett a legnagyobbat a mutató értéke, mely meghaladja az Egyesült Királyságban tapasztalt csökkenést is (az Európai országok közül itt történt a legnagyobb mértékü a visszaesés ) (3. ábra).

3. ábra. USA, Egyesült Királyság és Hollandia ISEW indexeinek százalékos összehas onlítása 1950 és 1995 között

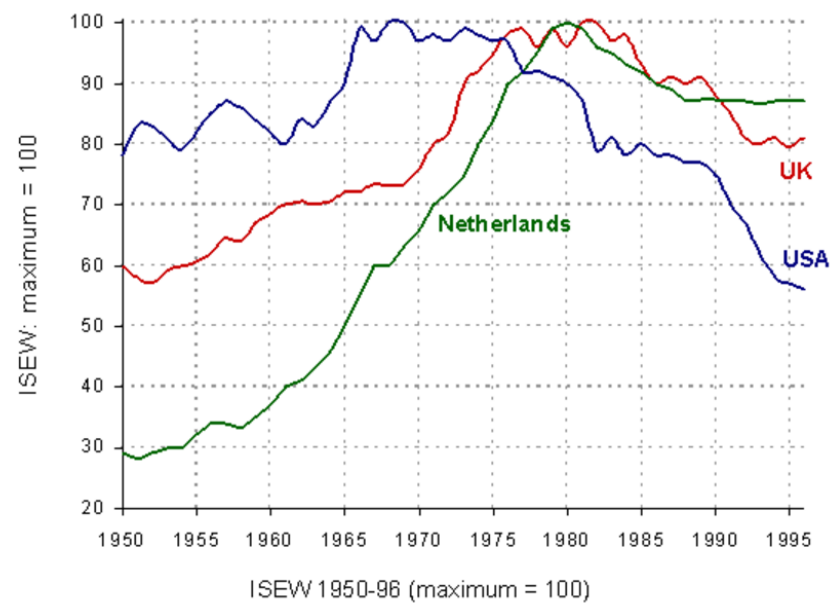

Forrás: http://wps.pearsoned.com.au/wps/media/objects/1634/1674144/case10_9.htm

${ }^{22}$ Hamilton, 1999. 


\section{Összefoglalás}

Munkánk a GDP felváltására, kiegészitésére kifejlesztett két legkorábbi és talán legismertebb alternatív jóléti mutató fejlődés ének történetét és tartalmát igyeks zik összefoglalni. Az ismertetést a gazdasági jólét mércéjével, azaz a MEW-val kezdtük, majd továbbfejlesztett változatával a fenntartható gazdasági jólét indexével, az ISEW-val folytattuk. Mindkét index GDP-hez mért újszerúsége számos ponton jelentkezik, azonban legfontosabb különbségüket a piac által nem közvetített tevékenységek és a környezeti károk számbavételében látjuk. Azadatok szubjektivitása és öss zegyüjtésének nehézsége folytán a MEW elterjedése marginális, és az ISEW -é is csak a világ fejlettebb térségeinek néhány országában érhető tetten.

Célunk az volt, hogy segítséget nyújtsunk és ötletet adjunk fiataloknak a diplomatervek és dolgozatok írásában, de talán a téma újszerüsége okán idősebb kutatók számára is szolgálhatunk újdonsággal. Csapatunk a közeljövőben is figyelni fogja a jóléti mutatók fejlődését, változásait, a megjelenő méréseket, amelyhez jelen munka szolgáltat számunkra alapot. Fontosnak tartjuk a fenntartható (gazdasági) fejlödés eszméjét, és a hozzá kapcsolódó eszközöket, így az alternatív mutatók feltérképezésével, hallgatóink figyelmét is erre kívánjuk irányítani.

A 2016-os KAKTUSZ környezetgazdasági szekciójának második munkacsoportja „A GPI, az SNBI és a HDI alternativ gazdasági mutatók elméleti áttekintése” címü dolgozatban ismerteti valódi fejlődés (GPI), a fenntartható nettó haszon (SNBI), a humán fejlettség indexét (HDI). ${ }^{23} \mathrm{E}$ tanulmány tekinthető jelen munkánk folytatásának.

\section{Irodalomjegyzék}

Ayres, R. U. (1998). A növekedésparadigma határai. Kovász, 37-60.

Bánfi, T. (2012). Társadalmi haszon, tisztesség és a GDP. Forrás: http://www.penzugyiszemle.hu/vitaforum/banfi-tamas-tars adalmi-has zontisztesseg-es-a-gdp, 2012. február 12.

Clarke, M., \& Lawn, P. (2008). Is measuring genuine progress at the sub-national level useful? Ecological Indicators 8., 573-581. DOI: 10.1016/j.ecolind.2007.08.002

Csuvár, Á., Bánkuti, Gy., Cseh, B. \& , Simon, S., \& Varga, J. (2018). A GPI, az SNBI és a HDI alternatív gazdasági mutatók elméleti áttekintése. Acta Scientiarum Socialium 49: 17-25.

Daly, H. E. (1990). Sustainable Growth: An Impossibility Theorem. Development. Róma.

Gerstberger, C., \& Yaneva, D. (2013). Analysis of EU-27 household final consumption expenditure - Baltic countries and Greece still suffering most from the economic and financial crisis. Statistics in focus 2/2013. Forrás: http://www.investmentgateway.eu/images/documents/EU27_household_final_ consumption.pdf

Hamilton, C. (1999). The genuine progress indicator methodological developments and results from Australia. Ecological Economics 30., 13-28. DOI: 10.1016/S09218009(98)00099-8

${ }^{23}$ Csuvár et al., 2018. 
Kerekes, S. (2007). A környezetgazdaságtan alapjai. Budapest: Aula.

Kerekes, S. (2015). Jó lehet-e a gazdaságnak, ami árt a Földnek? In G. Bakacsi, \& K. Balaton (szerk.), Vezetés és szervezet társadalmi kontextusban: Tanulmányok Dobák Miklós 60. születésnapja tiszteletére. Budapest: Akadémiai Kiadó, 319338.

Málovics, G. (2012.). A környezeti fenntarthatóság statisztikai mérőeszközeinek fejlesztésekor jelentkező operacionalizációs választások. Regionális innovációs képesség, versenyképesség és fenntarthatóság. Szeged: JATEPress.

Nordhaus, W. D., \& Tobin, J. (1972). Is Growth Obsolete? Economic Research: Retrospect vol. 5: Economic Growth, 81.

Péter, E. K. (2013). A külföldi munkavállalás társadalmi-, gazdasági jellemzői Hargita megyében. Editura: Presa Universitara Clujana, 128.

Unyi, I. (2007.). A magyarországi folyamatok értékelése az Európai Unió indikátorai tükrében. Budapest: BGF. Forrás: http://elib.kkf.hu/edip/D_13938.pdf

Yaneva, D., \& Gerstberger, C. (2013). Analysis of EU-27 household final consumption expenditure - Baltic countries and Greece still suffering most from the economic and financial crisis. Eurostat, Statistics in focus, 2013/2: 1-7.

A müre a Creative Commons 4.0 standard licenc alábbi típusa vonatkozik: CC-BY-NC-ND-4.0.

(cc) BY-NC-ND 